\title{
The Role of the Polri Intelligence in Securing the General Election and Institution of the Pidie District DPRK
}

\author{
Suhaibah $^{1}$, Armiwal ${ }^{2}$, Mukallaf ${ }^{3}$ \\ Faculty of Law, Universitas Jabal Ghafur, Indonesia \\ suhaibah@unigha.ac.id
}

\begin{abstract}
This research aims toknowingthe role of the Police Intelligence in securing the General Election and Inauguration of the Pidie Regency DPRK, the obstacles to the Intelligence of the Police in securing the General Election and the Inauguration of the DPRK and the efforts made to overcome the obstacles to the Police Intelligence in securing the General Election and Inauguration of the Pidie Regency DPRK In this study, the problem approach used was normative juridical and empirical juridical. Data collection was carried out by literature study and field studies. The data were analyzed qualitatively with data collection techniques through observation of library and field materials related to these problems. The results showed that the role of Police Intelligence in Securing the General Election and Inauguration of the Pidie Regency DPRK that is maintain and maintain a situation of security and national order in order to remain conducive since the preparatory stage, the election stage and the consolidation stage in order to ensure security for the public, election organizers in this case the KPU and Bawaslu, and Pilkada participants. Efforts Made to Overcome Police Intelligence Obstacles in Securing the General Election and Inauguration of the Pidie Regency DPRK by increasing organizational capabilities, individual capabilities, increasing security capabilities, increasing the ability to control activities and increasing additional capabilities.
\end{abstract}

Keywords role of intelligence; general election; DPRK

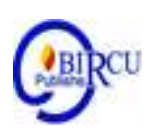

\section{Introduction}

Before and after the general elections or simultaneous elections in 2019 until the inauguration of DPRK members in Pidie Regency, the political temperature is increasing and general problems that will arise such as violations of campaign attributes, in addition to potential delays in sending DPT data and the resistance of political parties and KPU members regarding the qualification process selection and appointment of KPU commissioner members who are considered odd. The large number of parties who commit corruption is due to the expensive political system forcing political parties to seek funds as provisions for the winning process in the legislative and presidential elections in 2019.

This system does not only occur in the national legislative elections, but also occurs in the election of regional heads, both governors, Regents and Mayors, Regency / city legislative elections. Therefore, political parties make members of the executive as well as members of the legislature as "ATM machines" for funding the political activities of their political parties. For this reason, early detection efforts are needed by searching for and finding potential problems, as well as analyzing and implementing early prevention or early handling of any problems that arise in the General Election in Pidie Regency which is part of the duty of the POLRI intelligence. 
In relation to the implementation of the pilkada, the function of political parties also has a significant effect on the success of the election process. The success of holding the Pilkada is the level of success of the election as seen in terms of quantity and political quality. The realization of the functions of political parties will affect the level of political participation of the people in the elections. The functioning of political parties will also determine whether the elections that are held are political processes that educate and mature community politics or are merely political parties.

In the context of Indonesian politics, the imaging of political parties is often influenced bycindividual imagery. The dominance of personal image is often identified with the image of the institution (Azhar, 2018). Sutarto et al (2019) stated that Political imagery is formed based on information received, both directly and through political media. Political imagery is one of the effects of political communication in a paradigm or mechanistic perspective, which is generally understood as an inherent impression in the minds of individuals or groups. Nevertheless the image can be different from the real reality or does not reflect the objective reality. The political image as explained by Arifin is related to the formation of public opinion, because basically political public opinion is built through political image.

The correlation that occurs between the level of functioning of political parties and the success of the regional elections is that the higher the level of political parties (the functions of political parties are maximally realized), the more likely it will lead to the successful implementation of regional elections. Conversely, if the level of functioning of political parties is low, the implementation of regional elections will tend to be less successful. Pilkada can be an important turning point in the process towards a healthier democratic life, the pilkada provides an opportunity for the people to participate in the struggle to improve the future. It should be based on awareness and a sense of responsibility to be mentioned as a goal in a pilkada.

As for the candidates, political awareness enables them to follow the succession process with an honest and fair attitude and are ready to compete fairly, because winning or losing is a consequence of participating in the democratic process. For the community, through political education, it is hoped that it will be able to increase political awareness and increase public participation in the political process, so that "checks and balances" occur between the community and its leaders. Therefore, the role of intelligence is very influential in general elections and the inauguration of legislative members in order to be able to collect cyclical data. Data or information collection is carried out by intelligence agents assisted by informants in the field.

In addition, information can also be obtained from open sources such as the mass media. Intelligence agents have the ability to dig up information well. Extracting intelligence information does not use coercion, violence, or arrogance. The advantage of intelligence techniques is the search for information without realizing the source of the information. Intelligence agents will be involved in regional elections simultaneously. Intelligence agents can also use their informants or networks as sources of information. After the information is obtained, it will be sorted which is relevant and which is just information, then it will be analyzed. It is this information analysis process that shows intelligence as knowledge is capable of processing information into a POLRI intelligence product in the jurisdiction of the Pidie Police.

The role of POLRI intelligence in the jurisdiction of the Pidie Police in the context of general elections and inauguration of the DPRK serves to provide early detection and early warning to users, and by users or authorized parties this will be used as supporting material for decision makers. Apart from providing an early detection system and an early warning 
system, intelligence can provide recommendations for scenarios that the government can implement in dealing with conflicts. These scenarios include conflict prevention scenarios, conflict preparation scenarios, conflict emergency response scenarios, and post-conflict recovery scenarios. Based on the description above, the author is interested in researching legal writing in the form of a thesis with the title:

\section{Research Methods}

Data collection techniques were carried out to determine problems related to this study, which were obtained from sources, namely:

\subsection{Field Study}

The definition of field studies is a method to find specific and realistically about what is happening at some point in the midst of people's lives and aims to find primary data. Field studies can be carried out by means of observation and interviews. In this study, researchers used the interview method, the meaning of the interview is the process of obtaining information for research purposes by means of questions and answers by means of interviews with respondents.

\subsection{Literature Study}

The definition of literature study is a technique of collecting data by conducting a review of books, literature, notes and reports that are related to this research. Literature study / secondary data consists of:

\section{a. Primary Legal Materials}

- Government Regulation Number 27 of 1983 in conjunction with Government Regulation Number 58 of 2010 concerning Guidelines for Implementing the Criminal Procedure Code

- Chief of Police Decree Number: Kep / 37 / I / 2005 concerning Guidelines for Security Intelligence within the Indonesian National Police

- Law Number 2 of 2002 concerning the Indonesian National Police

- Regulation of the Head of the National Police Security Intelligence Agency of the Republic of Indonesia Number 2 of 2013 concerning Securing Intelligence of the Indonesian National Police

\section{b. Secondary Legal Material}

Secondary legal materials are materials that are closely related to primary legal materials such as scientific works of scholars, research results, and various other related sources. In this study, the authors used secondary legal materials, namely documents, research results, and related books.

\section{c. Tertiary Legal Materials}

Materials that provide information about primary and secondary legal materials, in this study, the authors use tertiary legal materials in the form of a legal dictionary and an Indonesian dictionary. 


\subsection{Data Analysis Methods}

The data obtained then went through the coding process, editing to answer the problem formulation, then analyzed based on the theoretical framework and understanding that developed when the author interpreted the data obtained by qualitative methods. The analytical method used is the deductive and inductive analysis method, because the deductive analysis method uses a general way of thinking from statements that are general in nature, specific conclusions are drawn, while the inductive analysis method emphasizes prior observations, then draws conclusions from specific to general based on these observations.

Both of these methods use value judgments which contain one or more premises to explain the method that should be taken using analytical tools, such as legal principles, legal theories, and related laws and regulations.

\section{Results and Discussion}

Based on intelligence detection and developments in the security situation in the field, the National Police has conducted an inventory of problems that could occur before, during or after the Pilkada. In addition, the National Police has also predicted several potential vulnerabilities that are expected to occur at each Pilkada stage, from the logistical printing stages, logistics distribution, to the inauguration / oath-taking stage of the elected regional heads. Potential vulnerabilities that arise can be normal, but can also result in disruption of the stability of domestic security if no anticipatory steps are taken as early as possible any problems that arise at the Pilkada stage, in the end it can also affect the Pilkada results. The emergence of various violations or problems during the announcement of the results of the Pilkada, does not rule out the possibility that it can be used as a tool by certain parties to question the validity of the elections that have been implemented. This condition has the potential to become a tool to delegitimize a Pilkada. If the delegitimation is massive, then the potential for vulnerability can occur in a very broad form. It is feared that the public's distrust of the results of the Pilkada could disrupt local government activities, because the elected local governments are considered to have been born from a flawed process. Then the potential for vulnerability can occur in a very broad form. It is feared that the public's distrust of the results of the Pilkada could disrupt local government activities, because the elected local governments are considered to have been born from a flawed process. Then the potential for vulnerability can occur in a very broad form. It is feared that the public's distrust of the results of the Pilkada could disrupt local government activities, because the elected local governments are considered to have been born from a flawed process.

Related to this situation the PolicePidie has alerted 240 personnel to secure the Pilkada which personnel are also prepared in the quiet period leading up to the election. In this case, the police and police appeal together to keep the situation safe and conducive, both before and after the Pilkada, and Polres hopes that the community will not be provoked by issues that will only make the situation unsafe. Regarding the potential for conflict related to the 2019 Pidie Pilkada The Pidie Police emphasized that they will carry out monitoring in all areas in Pidie Regency by involving all Polsek. In addition, his party will also continue to coordinate with the Election Supervisory Committee (Panwaslu) and the TNI so that the calm period is truly calm and is not used to campaign by pairs of candidates and supporters. The facts obtained from the results of the 2019 Pidie Regency Pilkada, the police found 12 conflict-prone points in the Pidie Regency Pilkada overshadowed the implementation of the 2019 Regional Head General Election (Pilkada). 
tinged with conflict. The potential for conflict-prone nature could indeed occur, because the pilkada in Pidie Regency was attended by 4 candidate pairs from various ethnicities and religions.

The process of early detection of intelligence at the Pidie Police was carried out not solely with modest information products but through various stages of processing data and also using in-depth analysis so as to produce accurate information. The information available is made in the form of intelligence products that are presented to the leadership to provide input to the leadership to help determine the policies to be taken to anticipate disruption of the social and security services. The leadership policy which is related to the anticipation of social security disturbances is very useful for creating a conducive community service, with this early detection, the leadership can determine the right policy steps, with the accuracy of these policies so that a security environment can be maintained in accordance with the main duties of the POLRI.

\section{Conclusion}

Based on the formulation of the problem, the following conclusions can be drawn:

1. The Role of Police Intelligence in Safeguarding the General Election and Inauguration of the Pidie Regency DPRK that is maintain and maintain a situation of security and national order in order to remain conducive since the preparation stage, the election stage and the consolidation stage in order to ensure security for the public, election organizers in this case the KPU and Bawaslu, and Pilkada participants themselves. Safeguarding and escorting each stage of the election, so as to be able to anticipate and eliminate potential disturbances or threats that may arise in the upcoming Pilkada. And the third is to enforce the law against violations, election crimes and other crimes as regulated in the applicable law.

2. Police Intelligence Obstacles in Safeguarding the General Election and Inauguration of the Pidie Regency DPRK, namely the lack of organizational capacity, the lack of individual capabilities of the National Police, the lack of increased security capabilities, the lack of increased mobilization capacity, the lack of authority activities so that the tactics and techniques they have are getting less and less. increased ability to control activities and the absence of additional abilities.

3. Efforts Made to Overcome Police Intelligence Obstacles in Securing the General Election and Inauguration of the Pidie Regency DPRK by increasing organizational capabilities, individual capabilities, increasing security capabilities, increasing the ability to control activities and increasing additional capabilities.

Based on the results of the discussion of the research results, the authors provide some suggestions and contributions as follows:

1. It is hoped that the POLRI intelligence can provide security in every general election and inauguration of the DPRK Pidie by means of the National Police's intelligence early detection system to get more understanding and attention so that it can carry out proper antisapi later when carrying out duties in the field.

2. It is hoped that the investigators, with the existence of an early detection system by the intelligence of the Indonesian National Police, will play a very important role in anticipating the threat of disruption to the social security that might occur, so that the intelligence products given to the leadership should be truly accurate.

3. It is hoped that all parties participate in maintaining public order and collaborating with law enforcers, so that public order can be guaranteed. 


\section{References}

Abdussalam, H. R. 2009. Hukum Kepolisian Sebagai Hukum Positif dalam Disiplin Hukum. Restu Agung, Jakarta.

A.S Alam,2010. Pengantar Kriminologi, Makassar: Refleksi Books

Arbi Sanit. 1997, Partai, Pemilu dan Demokrasi, Yogyakarta: Pustaka Pelajar, 1997

Ateng Syafruddin. 2003, Hubungan Kepala Daerah Dengan DPRD, Bandung: Tarsito.

Azhar, A.A. (2018). Marketing of Political Communication Created by National Mandate

Party (PAN) in General Election 2005-2015, North Sumatra, Indonesia. Budapest

International Research and Critics Institute-Journal (BIRCI-Journal). P. 93-106.

Barda Nawawi Arief. 2001, Masalah Penegakan Hukum dan Kebijakan Penanggulangan

Kejahatan, Bandung: Citra Aditya Bakti.

Barda Nawawi Arief. 2003, Kapita Selekta Hukum Pidana, Bandung: Citra Aditya Bakti

Chalid, Pheni. 2000, Peran Perwakilan Parlemen, Proper UNDP Indonesia

Jimly Asshiddiqie. 2005, Hukum Tata Negara dan Pilar-pilar Demokrasi. Serpihan Pemikiran Hukum. Media, dan HAM. Jakarta: Konstitusi Press

Hari Sasangka. 2003, Asas-Asas Hukum Pidana di Indonesia, Bandung: Refika. Aditama

Harahap, M. Yahya. 2000. Pembahasan Permasalahan dan Penerapan KUHAP. Sinar Grafika. Jakarta.

Himawan, Muammar. 2004. Pokok-Pokok Organisasi Modern. Bina Ilmu. Jakarta.

Lamintang, P.A.F. 1996. Dasar-Dasar Hukum Pidana Indonesia. Citra Adityta Bakti. Bandung.

Mamesah.2004, Sistem Administrasi Keuangan Daerah, Jakarta: Gramedia Pustaka Utama

Marpaung, Leden.2000. Tindak Pidana Terhadap Nyawa dan Tubuh (Pemberantasan dan Preverensinya), Sinar Grafika, Jakarta.

Moeljatno, 1993. Perbuatan Pidana dan Pertanggung jawaban Dalam Hukum Pidana, Bina Aksara, Jakarta

Nawawi Arief, Barda. 2001. Masalah Penegakan Hukum dan Kebijakan Penanggulangan Kejahatan. Citra Aditya Bakti. Bandung.

Ridwan, HR, 2009. Hukum Administrasi Negara, Jakarta: Rajawali Pers

Sanit,2011. Sistem Politik Indonesia, Kestabilan, Peta Kekuatan Politik dan Pembangunan, Jakarta : Rajawali

Sarundajang, 2001. Arus Balik Kekuasaan Pusat ke Daerah. Jakarta: Sinar Harapan,

Soerjono Soekanto. 2002. Sosiologi Suatu Pengantar. Jakarta: Rajawali Press.

Sutarto, et al. (2019). Political Imaging Techniques Carried Out by Baitul Muslimin Indonesia (BAMUSI) in Increasing Public Political Support for PDI Perjuangan Medan City. Budapest International Research and Critics Institute-Journal (BIRCIJournal). P. 164-174.

Titik Triwulan,2010. Kontruksi Hukum Tata Negara Indonesia Pasca Amademen UUD 1945, Jakarta: Kencana

Petrus Soerjowinoto dkk, 2014. Metode Penulisan Karya Hukum, Semarang : Fakultas Hukum Unika Soegijapranata.

Prakoso, Djoko,2007. Tindak Pidana Pemilu, Jakarta: Rajawali Pers. 